\title{
Customer Oriented Militants? \\ A critique of the 'Customer Oriented Bureaucracy' theory \\ on front-line service worker collectivism
}

\author{
Paul Brook, \\ Manchester Metropolitan University Business School, UK
}

\begin{abstract}
This critique challenges the Customer Oriented Bureaucracy (COB) theory's argument that the experience of customer service is pivotal to the formation of front-line service worker collectivism. COB's rejection of the major tenets of Marxist analysis, thereby denying the exploitative and class nature of service work, results in Korczynski theorising front-line worker collectivism as based only on the shared experience of doing customer service rather than as workers per se. As a neo-Weberian theory, COB argues 'consumer capitalism's' ideology of 'customer sovereignty' is a contemporary ideological 'iron cage' of value rationalisation in a unified, contradictory relationship with bureaucratic rationalisation. COB theory, consequently, allows only for a trade unionism that is limited to contesting the terms of customer service rather than challenging the deepening commodification of social relations.
\end{abstract}

\section{Key Words}

customer oriented bureaucracy /front-line /marxism / rationalisation / service / unions / weber

\section{Introduction}

The rising theoretical influence in recent years of the neo-Weberian body of work that characterises service organisations in contemporary 'consumer capitalism' as Customer Oriented Bureaucracies (COB) (Frenkel et al., 1999) has met with little critical resistance not least from its principal target, the Marxist cum labour process tradition. This theoretical contribution seeks to initiate just such an engagement by offering a critique from within the classical Marxist tradition (see Callinicos, 1999). In so doing, it focuses on Korczynski's (2002) extension of COB theory to account for front-line service workers' capacity to organise collectively and the political-strategic parameters of subsequent unionisation. While what follows ostensibly tackles the issue of front-line worker collectivism it is not a contribution that seeks to retread debates on union organising and workplace conflict in services nor account for local variations at the organisational, sectoral and national levels (see Korczynski, 2002; Royle and Towers, 2002; Gall, 2003). Rather, it tackles COB theory at its Weberian foundations.

Korczynski's (2002) central argument is that front-line service workers' experience is qualitatively different from that of back-office co-workers by virtue of 'doing' customer service within the context of the ever-strengthening ideology of customer sovereignty. This generates a theorisation of front-line collectivism where the management driven inculcation of customer-oriented values (underlain by capitalism's consumerist ideology) and increasing organisational bureaucratisation produces a trade unionism that is limited to contesting the terms of customer service in favour of the worker and customer. This conclusion is the result of COB theory's rejection of the major tenets of Marxism, principally the exploitative basis of the service labour process and its class 
nature deriving from capitalism's relations of production. Instead, its argument rests on Weber's theories of rationalisation and class where the latter is premised on life chances, power and status bestowed by the market (Weber, 1978). Korczynski's subsequent theorisation explains the existence of front-line collectivism as essentially deriving from the shared dissatisfaction of performing customer service work. It is unable, however, to account theoretically for collectivism arising in response to other grievances such as pay, conditions and management regime. COB theory, therefore, lacks the capacity to explain the existence of trade union organisation that unites frontline workers with back-office service employees and workers generally. The logical companion to this is a Weberian style denial of the feasibility of class-based resistance to the increasing commodification of social life (see Wright, 2002; Allen, 2004).

\section{Contradictory rationalisation}

COB's theoretical 'base camp' is Weber's concept of formal economic rationalisation, which sees bureaucratisation as a dominant, ever-deepening and inevitable process in industrial societies. This sits in conjunction with COB theory's acceptance that 'consumer capitalism' has elevated the 'myth of customer sovereignty' into today's predominant (ideological) substantive value rationalisation (Korczynski, 2001, 2003a). These two dimensions do not sit easily together as ' ...the rise of the customer as a focus of authority and identity creates potentially significant implications for (bureaucratised) production relations within service work. However, these are not totalizing implications (as organisational) control is best theorised as being informed by the dual logic of customer orientation and continuing rationalisation' (Korczynski et al., 2000: 684). Central to COB theory, therefore, is the construction of a Weberian ideal type service organisation common to 'consumer capitalism' characterised as a Customer Oriented Bureaucracy where the production of customer service necessitates dual and opposing objectives (Korczynski, 2003a).

The dual logic is a source of constant organisational contradiction and tension. Moreover, front-line service workers acutely experience these tense and contradictory pressures. In a continuous juggling act, they try to process the requisite quantity of customers within a prescribed format while relating to each customer as an individual with varying desires. Therefore, customer service is experienced as ' .... clash between the discipline, rationality and asceticism required in production and the indiscipline, irrationality and hedonism of consumption' (Korczynski, 2001: 82). This contradictory state is an inevitable condition of contemporary service production. Consequently, dayto-day, customer service creates a 'fragile social order' that is inherently unstable and subject to constant breakdown, reconstruction and amendment (Korczynski 2001; 2002).

Korczynski pays tribute to Ritzer's neo-Weberian 'McDonaldization' thesis (1996) by accepting his characterisation of contemporary bureaucratic rationalisation as generating routinised, scripted and dehumanised customer service. Ritzer is only half-right for Korczynski (2002), however, because he fails to acknowledge the existence of countervailing tendencies to McDonaldization, principally the 'myth of customer sovereignty' and its desire to enchant the hedonistic customer - the bi-polar opposite of bureaucratic asceticism. Thus, for COB theory there exist two contradictory processes of rationalisation - customer orientation and bureaucratisation - continually clashing and accommodating in their day-to-day co-existence, producing uncertain outcomes. For Weber (1978) and Ritzer (1996) there is little hope of escape from the 'iron cage' of 
bureaucratic rationalisation. COB theory, however, argues that there exists the prospect for front-line workers and customers to escape the 'disenchantment' of bureaucratisation via experiencing the enchantment of 'personalised' customer service (Korczynski 2005).

\section{Privileging customer service}

$\mathrm{COB}$ theory maintains that customer orientation is more than an imposed and necessary commercial condition for service organisations but rather a deeply infused social paradigm - a value rationalisation - where '... it becomes increasingly difficult to even find the language to contest an action which is justified in terms of it helping to serve the customer' (Korczynski, 2002: 48-9). Yet COB theory formally rejects the postmodernist assertion that the sphere of consumption, as opposed to production, is now the principal arena of social relations and self-identity formation. This is because the argument overstates the dominance of consumption and fails to conceptualise bureaucratic continuities from producer-dominant periods of capitalism. Consequently, customer sovereignty is a myth because it is 'one-eyed' and is better understood as the raised importance of the customer (Korczynski et al., 2000).

COB theory stresses that customer service involves a triadic relationship between frontline worker, customer and organisation. Korczynski $(2002 ; 2005)$ refutes the tendency to ascribe the customer as either an ally or enemy of the front-line worker. He argues that the producing organisation cannot presume to have unilateral determinative power over customer behaviour because in the act of seeking to structure the customer experience there is a desire to enchant which in itself presupposes customer agency. Customers, like front-line workers, seek a socially meaningful service experience within the context of the contradictory clash between their supposed sovereignty and the organisation's service norms. They adopt a complex range of stances at any given time and share front-line workers' frustration at the myth of sovereignty and the depersonalising pressures of service norms (see Bolton and Houlihan, 2005). For Korczynski (2005), the relationship between the customer and worker is not profoundly unequal, as argued by Hochschild (1983/2003). Rather, the contradictions of the service encounter afford workers the space to influence substantively the behaviour of the customer while the customer is able to experience a sense of sovereignty as '...the participants in the service interaction to some degree step outside of their economic role and interact socially' (Korczynski, 2004: 593).

Korczynski (2002) follows Leidner (1993) in stressing the importance of the socially embedded nature of service interactions, thereby implying that the potential pleasure derived from customer service is a principal source of job satisfaction for front-line workers. This is only achieved when the worker is able to fulfil a customer's expectations of enchantment and, in so doing, perpetuate the myth of customer sovereignty. A principal source of grievance, therefore, is worker frustration at not being able to deliver the level of service they believe is necessary to achieve enchantment. This occurs because front-line workers are regularly the victims of the COB contradiction; caught between the rigidities and targets imposed by the company bureaucracy and customers' realisation that their expectations of being sovereign are an illusion. To sustain this argument, COB theory rejects the notion that the systemic commodification of service and the fetishised nature of customer relations are alienating for the worker and the customer alike. Hence, Hochschild's (1983/2003) emotional labour thesis is criticised for its '... sole focus on the harm of emotional labour...' and 
'... that a fuller understanding of the social embeddedness of the economic exchange between service worker and customer allows a richer appreciation of the potential pleasures and meanings in emotional labour' (Korczynski, 2002: 155).

Aside from the pleasure and pain of customer interaction there is no attempt to theorise and integrate into the $\mathrm{COB}$ other sources of grievance and potential conflict that may be a shared experience with back-office workers in the same organisation. This is despite Frenkel et al's ad hoc assertion that '...only in relation to job security and co-worker relations could front-line workers be considered to be satisfied' (1998: 957). Instead, COB theory makes a careful distinction between 'front line' service work comprising socially embedded interaction (e.g. checkout operators and cabin crew) and back-office work (e.g. cleaners and baggage handlers) producing non-interactive service.

Consequently, the COB conceptualisation does '... not translate theoretically to the back office environment' (Korczynski, 2004: 112).

\section{Embryonic customer-oriented trade unionism}

Instability and fracture in the COB's 'fragile social order' affords front-line workers space to pursue the pleasurable, socially embedded side of customer work but always in the context of the pain from routinisation and pseudo customer relations. Yet this pain also in part generates another of the main pleasures of the job - '...the camaraderie experienced with colleagues in the face of adversity' (Korczynski, 2001: 98) pushing front-line workers to seek redress through informal collective strategies via the formation of mutual support networks but at the same time contributing to maintaining the 'fragile social order' (Korczynski, 2003b). These networks, called 'communities of coping', are forms of nascent solidarity from which trade unionism can emerge (Korczynski, 2003b). This is because communities of coping make the '... social order less open to management intervention' (2003b: 73) irrespective of the witting intentions of their members to merely offer mutual support. Thus, Korczynski (2002) argues that service work is 'fertile territory' for trade unionism. The twist in the argument is that it is an embryonic collectivism constrained by the customer-oriented desires of front-line workers (value rationalisation!). So in the case of flight crews the '...unspoken assumption is that conflict may exist for flight attendants, but that such conflict will only rarely become open: attendants tend to take a deep breath and smile back at the irate customer' (Korczynski, 2002: 177). Korczynski does accept, though, that union militancy is a feature of the service landscape by acknowledging the long history of conflict in the airline industry. Whether COB theory is able to accommodate such longterm union militancy in services is discussed later.

Arising from this conceptualisation of customer-oriented collectivism, Korczynski (2002) argues for a COB informed trade union strategy in services premised on a hybrid of the 'organising' and 'partnership' models currently central to debates on strategy in UK trade unionism (Heery, 2002). This is despite their apparent incompatibility. The 'organising' model rests on the self-activity of workers and contesting managerial legitimacy (Gall, 2001) generating a continuous struggle at the 'frontier of control' sustained by a class conflict ideology (Darlington, 2002). Conversely, the partnership model's ideological starting point is co-operation with employers via a pragmatic acceptance of corporate objectives and managerial legitimacy (Heery, 2002). 'Partnership', therefore, accepts the need for service workers to be imbued with customer-oriented and corporate values. What Korczynski (2002) does not acknowledge is that the organising model is also referred to as workplace unionism (Kelly, 1998). 
However, the terms are not inter-changeable as the use of 'organising' signals that the model is applicable only at the early stages of unionisation, that is, during the organising phase. The use of the term workplace unionism, by contrast, implies a more long-term, strategic and ideological orientation.

In practice, of course, the picture is more complex than is suggested by the models' dichotomous definitions (Gall, 2001). The crucial point is that 'organising - workplace' and 'partnership' unionism have central tenets of belief offering diametrically opposed perspectives on the desirability of management driven customer-oriented work.

Korczynski's own interpretation of the respective models' implications for service work downplays these contrasting ideological differences. Rather than understanding them as distinct political alternatives, he suggests that it is a matter of which one to select as a strategy depending on the pre-existing state of industrial relations:

If contemporary service work is seen as offering a greater potential for interests shared between management and workforce then a partnership approach makes sense... (Unions) must still be democratic, but in a representative rather than participative sense, and the sustaining ideology of trade unionism is one of placing trade unions as a legitimate actor within a stakeholder organisation and society. (2002: 178)

(If) service work is seen as increasingly steeped in conflict between management and the workforce, then an organising model is the more appropriate one. Here unions seek to break into non-unionised areas where the workforce is likely to be subject to greater exploitation, and to focus their action on issues of conflict with management... (T)he mobilisation of the membership may be necessary to keep forcing the employers' hand and the sustaining ideology is that of class conflict. (2002: 179-80)

The characterisation of the models as principally strategies with sustaining ideologies contingent upon changing circumstances is a denial of them as expressions of alternative political workplace strategies. Korczynski is thus able to follow Heery (2002) in arguing that an 'either or' approach is undesirable because '...if a central characteristic of contemporary work is its contradictory nature, then union strategies must reflect this, implying an interplay and dynamic between elements of the two approaches' (2002: 180). Furthermore, by limiting the applicability of the organising model to non-unionised contexts he effectively dismisses it as a basis for long-term union organisation and activity.

In practice, even the most combative unions make tactical decisions resulting in retreats, and accommodation with management. None of this means, however, that there is agreement with employers over their corporate objectives. Yet the notion of 'cooperation' in the partnership model requires just that. As Kelly argues, '... militancy and moderation are best understood as two ends of a continuum' (1998: 60-1) because unions are not free agents as they are subject to external constraints imposed by employers, the state, economics, etc. when it comes to their goals, methods and resources. Hence, any ' ... observed degree of union militancy and moderation therefore results from an interaction between unions and their environments and cannot necessarily be regarded as a true measure of the preferences of the union' (1998: 61).

Korczynski's portrayal of conflict and co-operation as complementary is only possible by conflating co-operation with tactical accommodation. He is able, therefore, to effectively dismiss the significance of fierce political debates within unions on their role and objectives, especially during industrial action (Darlington, 2002), political protest 
and union elections (Smith, 2005). These battles for the right to interpret and articulate members' interests are invariably between those groups of activists arguing for an interpretation and strategy based on class struggle and those who reject the existence of a profound structural class antagonism (see Kelly, 1998; Darlington, 2002; Gall, 2003). Despite this continuous organisational struggle, for Korczynski, unions' choice of strategy and ideology is one of expediency rather than profound political differences.

Korczynski's argument is in keeping with COB theory's Weberian concept of class. His implied notion of collectivism is one founded solely on the expediency of articulated shared interests, exemplified by front-line 'communities of coping'. It is a concept of collectivism, following Weber, defined by 'life chances', status and power bestowed by the capitalist market rather than one deriving from workers' response to the exploitation and domination inherent in their relationship with capital as argued by Marxism:

Employers hire workers and seek to exploit their capacity to work in order to produce both value (sufficient to cover the worker's wage or salary) and surplus value (to cover the employer's profit as well as interest, rent and dividends to shareholders. It is this inevitable exploitation and domination of labour by capital that creates the conflict of interest between the social classes. (Kelly, 1998: 25)

Like Weber (Wright, 2002), Korczynski rejects the notion that class is an objective relation to capital existing irrespective of workers' conscious, collective expressions of solidarity. This, in turn, is theoretically disabling:

\begin{abstract}
Weber's overall argument was that capital and labour were not the main protagonists within the present system. Each side was internally fragmented and 'class conflict' took place between varieties of groups, which were formed in the market place. Workers had few common interests since the focus was on the market rather than exploitation in the sphere of production... Weber could not theoretically explain how shared economic interest of workers gives rise to class conscious organisations so 'workers' resistance has no theoretical foundation... (Allen, 2004: 85-6)
\end{abstract}

Korczynski suffers the same theoretical fate as Weber by arguing 'communities of coping' are defined by front-line workers' shared role in producing service and their negative experiences of customers rather than as expressions of a collective solidarity arising from common class experiences of domination by management and formal subjugation to customers. COB theory is rendered silent regarding the basis on which back-office workers can affiliate and build a common collective consciousness with their front-line co-workers. Korczynski is left offering no more than a narrow set of sectional demands on improving customer service for the worker and customer as the core strategic objective for service unionism aimed at '... structuring the service encounter to minimise the dark side of the customer surfacing, and to minimise it when it does surface' (2002: 183).

\title{
Pro-customer trade unionism and its limits
}

Korczynski argues the bureaucratised side of customer service frequently undermines the potential for meaningful and pleasurable customer relationships. This does not imply an anti-management stance because service management also pursues customer orientation although not necessarily to the degree, and in ways, desired by staff and customers. Therefore, management too are victims of the dual logic, as it ' ... must walk down its own fine lines, erring on one side and then the other over time, aware that its standards are double' (Korczynski, 2002: 185). 
The logical companion to the COB's contradictory tensions acting as a principal source of worker grievance is that there is a rejection of service workers being subject to an 'intensification of work' and 'speed up' as this implies an 'anti-boss' imagery and managerial culpability. Instead, Korczynski (2002) prefers to explain such phenomena as an extension of the bureaucratised rationalisation of work, thereby denying management are the agents of exploitative capital. What remains is a Weberian contested legitimacy between workers and management over the interpretation of good customer service that, in turn, allows Korczynski to let management off the culpability hook:

\footnotetext{
What type of customer is being projected as the source of authority? Is it the disembodied 'average' customer that management appears to prioritize, or is it the socially embedded specific individual customer with whom service workers have empathy? ... Increasingly these become the key contested questions of ... legitimacy within the organizations of consumer capitalism. (2003a: 273)
}

Here is the nub of Korczynski's theoretical premise. By arguing that the key contested questions in the front-line are now over the quality of customer service his only theoretical basis for maintaining that service regimes are fertile territory for unionisation is that the COB continually frustrates front-line workers' desire for meaningful relations with customers. Even this is debatable, as it relies on management's ability to manufacture a believable vision of potential job satisfaction in order to preserve it as a realistic aspiration. Taylor and Bain (2001) argue that their own call centre evidence contradicts the claims of the $\mathrm{COB}$ adherents about the degree of satisfaction front-line workers can extract from customer relationships. They conclude that whether '...labour is performed at the qualitative, or more commonly, the quantitative end of the spectrum, the majority of call centre operators experience managerial control frontiers as oppressive, far more than Frenkel et al. acknowledge' (2001: 61). Even in the hi-skill and hi-pay world of 'professional' services where the client is sovereign rather than the customer the regime can still be experienced as oppressive. Anderson-Gough et al. (2000) in their study of international accountancy firms found that managerial control was exercised via a discourse of privileging the 'demanding client'. This refracted the source of demands for behavioural compliance and commercial competitiveness so much that staff frequently resorted to blaming the client for management negotiated tight deadlines and unsocial hours. Apparently, even 'professional' regimes are not immune to the pleasure side of client service becoming an aspiration tarnished by the systemic demands of capitalist accumulation via the agency of management.

\section{Conceptual fog}

COB theory's reliance on the 'invisible hand' of deepening rationalisation creates a conceptual fog when seeking to explain against what and whom front-line workers are supposed to organise. This is because it closes off the possibility that the competitive and exploitative nature of capitalism driving the COB's contradictory logic is also responsible for the intensification of work via the agency of management. COB fails to theorise the implications for work relations and workers' collective consciousness of the corporate search for ever-greater levels of effort, productivity, profit and competitiveness - increasing the rate of exploitation. Nor does it address the systemic role played by management in attempting to secure greater 'productivity' from service workers. COB theory, therefore, is unable to explain why many studies continue to find 
that the issues of pay, conditions and management regime remain central drivers to unionisation along side demands for customer service improvements (Gall, 2003).

Korczynski's implied argument that the customer-oriented commitment of front-line staff - a manifestation of value rationalisation - severely constrains the possibility of a thriving adversarial unionism also contradicts much of the evidence. Combative, antimanagement attitudes are prevalent not just in airlines or at the initial organising stage of service unionisation but can also develop over time where there is an established union presence such as in UK financial services:

\footnotetext{
...there is real derision at the way they're being treated... and this is feeding through to them beginning to learn the traditions of what we associate with 'old fashioned' trade unionism; more widespread 'them and us' attitudes; more confidence and organisation to mount a fight. (Bifu Clydesdale member quoted by Gall: 2001: 357)
}

This is not to say adversarial unionism is widespread in services or inevitable over time but that it is possible and not uncommon. Paradoxically, Korczynski notes that '...public sector workplaces have been where the rise of consumer authority has been experienced most sharply' (2003a: 268). Yet front-line public sector workers and those in privatised services provide some of the best contemporary examples of sustained trends in adversarial trade unionism such as the UK's civil servant, fire fighter, post and rail unions (Smith, 2005). Elsewhere, the French SUD federation (Jefferys, 2003) and the Italian COBAS movement (Ginsborg, 2001) have emerged and grown rapidly as militant 'rank and file' unions explicitly committed to the defence of working class interests. In SUD and COBAS it is front-line public sector workers - especially in postal services, education and transport- who play central roles.

Related to the issue of front-line workers' potential to pursue militant unionism is the question of popular social ideas feeding into and shaping anti-management and anticorporate sentiment. The anti-capitalist movement, par exemplar, has fanned, organised, connected and given ideological expression to popular anti-corporate sentiment (Klein, 2001) and otherwise isolated opposition to neo-liberal marketisation of employment and public services (Harvey, 2005). With slogans such as 'our world is not for sale' encapsulating a widespread opposition to consumerism's reduction of social interaction to marketised customer relations it raises the question of to what extent can workers imbued with customer-oriented values be immune to the counter-challenge of anticapitalist ideas? Korczynski is silent on this point because COB theoretically closes off the possibility of anti-consumerist ideas competing with the corporate driven ideology of customer orientation. This is because it understands the rise of customer authority to be a new process of value rationalisation, thereby, possessing a privileged position in the arena of ideological struggle. Korczynski's theorisation, in effect, grants customer orientation near immunity to ideological competition from anti-capitalist argument. The practical consequence for service trade unionism is that COB theory sees only the possibility of front-line workers contesting the terms of customer service rather than questioning its very desirability as exploitative and alienating for both parties (Cox, 1998). The outcome is a conservative theorisation of front-line service worker trade unionism.

\section{Conclusion}

$\mathrm{COB}$ theory suggests that for front-line workers the rise of customer authority has made customer service the pivotal moment of their work experience. The theoretical 
implication being that front-line worker unionism should organise principally around winning improvements in the quality of the customer service experience for the worker and customer alike. This produces a twofold argument. First, front-line workers are qualitatively different to other workers owing to their experience of customer service as socially embedded and its potential to be fulfilling for worker and customer alike. This coincidence of interests enables potential solidarity between front-line workers and customers. Second, there is a theoretical closure on front-line collectivism emerging in response to the common class experiences of exploitation and domination by management. Therefore, Korczynski is unable to account for front-line collective unity with back-office co-workers and other workers but can explain solidarity with customers.

This closure is because managers are co-victims of COB's contradictions. As the custodians of customer service norms (bureaucratic rationalisation), they are sources of both pleasure and pain for staff. They are not, however, the agents of systemic exploitation as argued by the Marxist cum labour process traditions where what COB identifies as deepening bureaucratic rationalisation is understood as the intensification of labour and an increase in the rate of exploitation. Consequently, Korczynski's argument for unionisation essentially downplays, if not rejects, the potential for strategic workplace unionism because its rationale is a continual challenge to the 'frontier of control' based on the premise that management's corporate objectives are illegitimate. Related to this is the assumption that a sustaining trade union ideology based on questioning 'consumer capitalism's' extolling of the customer is effectively unassailable as an idea and practice. For Korczynski, unions can only contest the terms of customer service, not the architecture of a capitalist society increasingly suffused by the alienation of commodified relationships.

\section{References}

Allen, K. (2004) Max Weber. London: Pluto.

Anderson-Gough, F., Grey, C. and Robson, K. (2000) 'In the name of the client: the service ethic in two professional service firms', Human Relations 53 (9): 1151-74.

Bolton, S.C. and Houlihan, M. (2005) 'The (mis)representation of customer service', Work, Employment and Society 19 (4): 685-703.

Callinicos, A. (1999) Social theory: an historical introduction. Cambridge: Polity.

Cox, J. (1998) 'An introduction to Marx's theory of alienation', International Socialism 79: 41-62.

Darlington, R. (2002) 'Shop stewards' leadership, left wing activism and collective workplace union organisation', Capital \& Class 76: 95-126.

Frenkel, S.J., Korczynski, M., Shire, K.A. and Tam, M. (1999) On the Front Lineorganization of work in the information economy. London: Cornell University.

Gall, G. (2001) 'From adversarialism to partnership? Trade unionism and industrial relations in the banking sector in the UK', Employee Relations 23(4): 353-75. 
Gall, G. (ed.) (2003) Union Organizing. London: Routledge.

Ginsborg, P. (2001) Italy and its Discontents. London: Allen Lane.

Heery, E. (2002) 'Partnership versus organising: alternative futures for British trade unionism', Industrial Relations Journal 33(1): 20-35.

Harvey, D. (2005) Neoliberalism. Oxford: OUP

Hochschild, A. (1983/2003) The Managed Heart: commercialization of human feeling. London: University of California.

Jefferys, S. (2003) Liberté, Égalité and Fraternité at Work: changing French employment relations and Management. Basingstoke: Palgrave-Macmillan.

Kelly, J. (1998) Rethinking Industrial Relations. London: Routledge.

Klein, N. (2001) No Logo. London: Flamingo.

Korczynski, M. (2001) 'The contradictions of service work: call centre as Customer Oriented Bureaucracy' in A. Sturdy, I. Grugulis and H. Willmott (eds.) Customer Service: Empowerment and Entrapment, pp.79-101. London: Palgrave.

Korczynski, M. (2002) Human Resource Management in Service Work. Basingstoke: Palgrave.

Korczynski, M. (2003b) 'Communities of Coping: Collective Emotional Labour in Service Work', Organization 10(1): 55-79.

Korczynski, M. (2003a) 'Consumer Capitalism and Industrial Relations' in P. Ackers and A. Wilkinson (eds.) Understanding Work \& Employment, pp. 265-77. Oxford: OUP.

Korczynski, M. (2004) 'Back-office service work: bureaucracy challenged? Work, Employment and Society 18(1): 97-114.

Korczynski, M. (2005) 'The point of selling: capitalism, consumption and contradictions'. Organization 12(1): 69-88.

Korczynski, M., Shire, K., Frenkel, S. and Tam, M. (2000) 'Service Work in Consumer Capitalism: Customers, Control and Contradictions', Work, Employment and Society 14 (4): 669-87.

Leidner, R. (1993) Service Work and the Routinization of Everyday Life. London: University of California.

Ritzer, G. (1996) The McDonaldization of Society: an investigation into the changing character of contemporary life. Newbury Park, C.A.: Pine Forge Press. 
Royle, T. and Towers, B. (eds.) (2002) Labour Relations in the Global Fast Food Industry. London: Routledge.

Smith, M. (2005) 'Politics and the struggle', International Socialism 105: 111-123.

Taylor, P. and Bain, P. (2001) 'Trade unions, workers' rights and the frontier of control in UK call centres', Economic and Industrial Democracy 22(1): 39-66.

Weber, M. (1978) Economy and Society. Berkeley: University of California.

Wright, E. O. (2002) 'The shadow of exploitation in Weber's class analysis', American Sociological Review 67 (December): 832-853.

\section{Paul Brook}

Paul Brook is a Senior Lecturer at Manchester Metropolitan University Business School. His research interests include Marxist and Labour Process theory, front-line customer service work and trade unionism in services. He is currently working on a reevaluation of Hochschild's foundational use of Marx's theory of alienation in her emotional labour thesis.

Address: Manchester Metropolitan University Business School, Aytoun Building, Aytoun Street, Manchester M1 3GH, UK. E-mail: p.brook@mmu.ac.uk 